\title{
Involvement of catalase and superoxide dismutase in hydrophobic organic solvent tolerance of Escherichia coli
}

Noriyuki Doukyu ${ }^{1,2^{*}}$ (D) and Katsuya Taguchi ${ }^{1,2}$

\begin{abstract}
Escherichia coli strains are generally sensitive to hydrophobic organic solvents such as $n$-hexane and cyclohexane. Oxidative stress in E. coli by exposure to these hydrophobic organic solvents has been poorly understood. In the present study, we examined organic solvent tolerance and oxygen radical generation in E. coli mutants deficient in reactive oxygen species (ROS)-scavenging enzymes. The organic solvent tolerances in single gene mutants lacking genes encoding superoxide dismutase ( $\operatorname{sod} A$, sodB, and sod $)$, catalase (katE and katG), and alkyl hydroperoxide reductase (ahpCF) were similar to that of parent strain BW25113. We constructed a BW25113-based katE katG double mutant (BW25113 kkatE $\Delta k a t G$ ) and sodA sodB double mutant (BW25113sodA $\triangle$ sodB). These double-gene mutants were more sensitive to hydrophobic organic solvents than BW25113. In addition, the intracellular ROS levels in E. coli strains increased by the addition of $n$-hexane or cyclohexane. The ROS levels in BW25113 $\triangle$ katE $\triangle k a t G$ and $B W 25113 \triangle$ sodA $\triangle$ sodB induced by exposure to the solvents were higher than that in BW25113. These results suggested that ROS-scavenging enzymes contribute to the maintenance of organic solvent tolerance in $E$. coli. In addition, the promoter activities of $\operatorname{sod} A$ and $\operatorname{sod} B$ were significantly increased by exposure to $n$-hexane.
\end{abstract}

Keywords: Escherichia coli, Organic solvent tolerance, Catalase, Superoxide dismutase, Reactive oxygen species

\section{Introduction}

Efficient microbial production of valuable organic compounds including biofuels and fine chemicals from renewable biomass resources is one of the crucial challenges in the establishment of a sustainable society. Some of these valuable chemicals such as advanced biofuels and bulk chemicals, including organic solvents including 1 -octanol and styrene, are toxic to various microorganisms such as E. coli and Pseudomonas putida (Akhtar et al. 2015; Lennen et al. 2013; Mukhopadhyay 2015). Accumulation of these toxic products can negatively impact the viability of microbes and impede their efficient mass production of organic compounds (Doukyu

\footnotetext{
*Correspondence: dokyu@toyo.jp

${ }^{1}$ Department of Life Science, Toyo University, 1-1-1 Izumino,

Itakura-machi, Gunma 374-0193, Japan

Full list of author information is available at the end of the article
}

and Iida 2020; Doukyu et al. 2003; Mukhopadhyay 2015). Bacterial growth and stress response have been studied in a variety of organic solvents (Heipieper et al. 2007; Inoue and Horikoshi 1989; Ramos et al. 2002). Solvents with higher hydrophobicity tend to increase in toxicity (Kabelitz et al. 2003). At saturated concentrations, the toxicity of the hydrophobic organic solvent is inversely correlated with the $\log P_{\text {ow }}$ of the solvent (common logarithm of partition coefficient of given solvent in a mixture of n-octanol and water) (Inoue and Horikoshi 1989). In the $\log P_{\text {ow }}$ range of 2 to 4 , increasing the hydrophobicity of the solvent could enhance the level of toxicity (Kabelitz et al. 2003). The effects of organic solvents on membrane structure and fluidity differ depending on the polarity of the solvent (Griepernau et al. 2007).

It has been reported that reactive oxygen species (ROS) are generated in Escherichia coli during exposure to hydrophilic solvents such as ethanol and $n$-butanol 
(Cao et al. 2017; Chin et al. 2013; Rutherford et al. 2010). A ROS assay using a cell-permeant fluorescent dye showed a significant increase in intracellular ROS levels in $n$-butanol-exposed $E$. coli cells (Rutherford et al. 2010). In addition, an $E$. coli strain expressing metallothioneins, which function in ROS scavenging, exhibited an increased growth rate under $n$-butanol stress (Chin et al. 2013). Thus, ROS generation has been suggested to be attributable in part to the toxicity of hydrophilic organic solvents. On the other hand, various tolerance mechanisms in E. coli strains have been studied with hydrophobic organic solvents such as $n$-hexane and cyclohexane (Aono 1998). These findings are useful for improving the production of hydrophobic solvents and fatty acids (Akhtar et al. 2015; Lennen et al. 2013). However, little is known about the ROS generation in microbial cells by these hydrophobic organic solvents.

Various ROS, including superoxide, $\mathrm{H}_{2} \mathrm{O}_{2}$ and hydroxyl radical, are generated as by-products in cells grown aerobically. Specific enzymes such as catalase and superoxide dismutase (SOD) decrease the levels of cytotoxic ROS. $E$. coli harbors two different catalase genes: katG, which encodes hydroperoxidase I (HPI) (Triggs-Raine et al. 1988) and katE, which encodes HPII (Mulvey et al. 1988). HPI is induced by $\mathrm{H}_{2} \mathrm{O}_{2}$ in an OxyR-dependent manner, while expression of HPII is dependent on a sigma factor, RpoS (Mukhopadhyay and Schellhorn 1994). The activities of both catalases increase as the growing cells enter stationary phase. In addition, the genome of $E$. coli includes the alkyl hydroperoxide reductase gene $(a h p C F)$, which scavenges $\mathrm{H}_{2} \mathrm{O}_{2}$ and organic hydroperoxides (Ferrante et al. 1995; Smillie et al. 1992). E. coli possesses three distinct SOD genes: $\operatorname{sod} A$, which encodes a cytosolic manganese-containing SOD (Touati 1983), $\operatorname{sodB}$, which encodes a cytosolic iron-containing SOD (Sakamoto and Touati 1984) and $\operatorname{sod} C$, which encodes a periplasmic copper and zinc-containing SOD (Imlay and Imlay 1996). SodC is induced in stationary phase and seems to be important to protect the cell from exogenous ROS attacks (Gort Amy et al. 2002).

Both the katE katG double mutant and $\operatorname{sod} A \operatorname{sodB}$ double mutant are sensitive to $\mathrm{H}_{2} \mathrm{O}_{2}$ due to DNA damage (Imlay and Linn 1987; Ruiz-Laguna and Pueyo 1999). In addition, ROS levels significantly increased in $\operatorname{sod} A$ $\operatorname{sodB}$ double mutant by the addition of $p$-nonylphenol (Okai et al. 2004). Thus, it was suggested that one of the primary actions of $p$-nonylphenol in cells is the generation of superoxide.

In this study, we examined the involvement of catalase and SOD genes in organic solvent-tolerance in E. coli. We found that two BW25113-based mutants, the $\Delta k a t E \Delta k a t G$ mutant and $\Delta \operatorname{sod} A \Delta \operatorname{sodB}$ mutant, were highly sensitive to organic solvents. In addition, it was shown that the increases in intracellular ROS levels in these two mutants were larger than that in strain BW25113 when these strains were treated with hydrophobic organic solvents. These results showed that catalase and SOD are implicated in the organic solvent tolerance in E. coli.

\section{Materials and methods}

\section{Media, culture conditions and materials}

E. coli strains were grown aerobically at $37^{\circ} \mathrm{C}$ in LBGMg medium consisting of $1 \%$ tryptone, $0.5 \%$ yeast extract, $1 \% \mathrm{NaCl}, 0.1 \%$ glucose, and $10 \mathrm{mM} \mathrm{MgSO}_{4}$ (Aono et al. 1991). The LBGMg medium was solidified with $1.5 \%$ (wt/ vol) agar. Ampicillin $(50 \mu \mathrm{g} / \mathrm{ml})$ or kanamycin $(50 \mu \mathrm{g} /$ $\mathrm{ml}$ ) was added to the medium when necessary. Lysogeny broth (LB) agar medium was used for measuring colonyforming units (Neidhardt et al. 1974). M9 medium was used for ROS assay (Neidhardt et al. 1974). Growth of cells in liquid culture was monitored by measuring the optical density at $660 \mathrm{~nm}\left(\mathrm{OD}_{660}\right)$. The tert-butyl hydroperoxide was obtained from FUJIFILM Wako Pure Chemical Industries (Osaka, Japan). The organic solvents used were of the highest quality available (FUJIFILM Wako Pure Chemical Industries). The $\log P_{\text {ow }}$ values of the hydrophobic solvents used in this study were as follows: cyclooctane $\left(\log P_{\text {ow }}, 4.1\right), n$-hexane $\left(\log P_{\text {ow }}, 3.9\right)$ and cyclohexane $\left(\log P_{\text {ow }}, 3.4\right)$.

\section{Bacterial strains and plasmids}

The E. coli strains and plasmids used in this study are summarized in Tables 1 and 2, respectively. Strain BW25113 and its single-gene knockout mutants were obtained from the National Bio-Resource Project (NIG, Mishima, Japan) (Baba et al. 2006). The plasmid pCP20 was also supplied by NIG. pMC1403 contains a sequence downstream of the 10th codon of lac $Z$, but it does not contain the lac $Z$ promoter, the Shine-Dalgarno sequence, and the start codon (Casadaban et al. 1980). The plasmid pMW119 was purchased from Nippon Gene (Tokyo).

\section{Construction of BW25113 $\Delta$ katEAkatG and BW25113 $\Delta$ sod $A \Delta$ sodB}

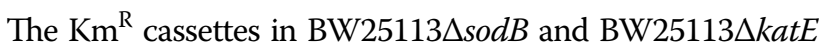
were eliminated with pCP20 (Cherepanov and Wackernagel 1995). Elimination of the $\mathrm{Km}^{\mathrm{R}}$ cassette was confirmed by PCR analysis using chromosomal DNA. The combination of primers for BW25113 $\Delta$ sodB was sodB-S and sodB-AS, and that for BW25113 $\Delta$ katE was katE-S and katE-AS (Table 3).

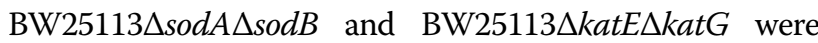
constructed from the $\mathrm{Km}^{\mathrm{R}}$ cassette-eliminated mutants BW25113 $\Delta \operatorname{sodB}$ and BW25113 $\Delta$ katE by P1 transduction 
Table 1 Escheria coli strains used in this study

\begin{tabular}{|c|c|c|c|}
\hline Strain & $J W I^{a}$ & Relevant characteristics & References \\
\hline BW25113 & & $\operatorname{lac}^{19} \mathrm{rrnB}_{\mathrm{T} 14} \operatorname{lac}_{\mathrm{WJ16}}$ hsdR514 araBAD $\mathrm{AH}_{\mathrm{AH}}$ rhaBAD $\mathrm{LD}_{\mathrm{LD} 8}$ & (Baba et al. 2006) \\
\hline BW25113 $\Delta k a t E$ & JW1721 & Same as BW25113, but with katE::Km ${ }^{R}$ & (Baba et al. 2006) \\
\hline BW25113 $\Delta k a t G$ & JW3914 & Same as BW25113, but with katG::Km ${ }^{R}$ & (Baba et al. 2006) \\
\hline 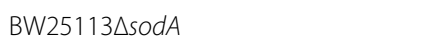 & JW3879 & Same as BW25113, but with sodA::Km & (Baba et al. 2006) \\
\hline BW25113 $\triangle$ sodB & JW1648 & Same as BW25113, but with sodB::Km ${ }^{R}$ & (Baba et al. 2006) \\
\hline BW25113 ssodC & JW1638 & Same as BW25113, but with sodC::Km & (Baba et al. 2006) \\
\hline BW25113 $\Delta \mathrm{ahpF}$ & JW0599 & Same as BW25113, but with ahpF::Km ${ }^{R}$ & (Baba et al. 2006) \\
\hline BW25113 $\Delta$ katE $\Delta k a t G$ & & Same as BW25113, but with $\triangle k a t E$ and $\Delta k a t G$ & This study \\
\hline BW25113 $\triangle$ sodA $\triangle$ sodB & & Same as BW25113, but with $\triangle$ sod $A$ and $\triangle \operatorname{sod} B$ & This study \\
\hline BW25113(pMW119) & & BW25113 harboring pMW119 & This study \\
\hline BW25113 $\Delta k a t E \Delta k a t G(p M W 119)$ & & 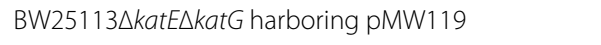 & This study \\
\hline 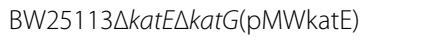 & & 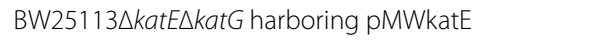 & This study \\
\hline 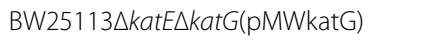 & & 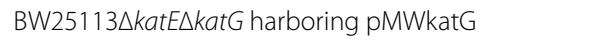 & This study \\
\hline 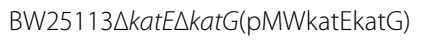 & & BW25113 $\Delta$ katE $\Delta k a t G$ harboring pMWkatEkatG & This study \\
\hline 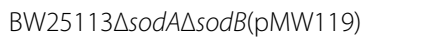 & & BW25113 $\triangle$ sodA $\triangle$ sodB harboring pMW119 & This study \\
\hline BW25113 $\triangle$ sodA $\triangle$ sodB(pMWsodA) & & BW25113 $\triangle$ sodA $\triangle$ sodB harboring pMWsodA & This study \\
\hline BW25113 $\triangle$ sodA $\triangle$ sodB(pMWsodB) & & BW25113 $\triangle$ sodA $\triangle$ sodB harboring pMWsodB & This study \\
\hline BW25113 $\triangle$ sodA $\triangle$ sodB(pMWsodAsodB) & & BW25113 $\triangle$ sodA $\triangle$ sodB harboring pMWsodAsodB & This study \\
\hline BW25113(pMCkatEp) & & BW25113 harboring pMCkatEp & This study \\
\hline BW25113(pMCkatGp) & & BW25113 harboring pMCkatGp & This study \\
\hline BW25113(pMCsodAp) & & BW25113 harboring pMCsodAp & This study \\
\hline BW25113(pMCsodBp) & & BW25113 harboring pMCsodBp & This study \\
\hline
\end{tabular}

a JW ID of the Keio Collection by the National Bio-Resource Project (NIG, Mishima, Japan): E. coli (Baba et al. 2006)

Table 2 Plasmids used in this study

\begin{tabular}{|c|c|c|}
\hline Plasmids & Relevant characteristics & References \\
\hline pCP20 & pSC101-based vector expressing the Flp recombinase with repA(Ts), Ampr $\mathrm{Cm}^{r}$ & $\begin{array}{l}\text { (Cherepanov and } \\
\text { Wackernagel 1995) }\end{array}$ \\
\hline pMW119 & Expression vector with the replication origin of pSC101, Ampr & Nippon Gene \\
\hline pMWkatE & pMW119-based plasmid carrying katE & This study \\
\hline pMWkatG & pMW119-based plasmid carrying katG & This study \\
\hline pMWkatEkatG & pMW119-based plasmid carrying katE and katG & This study \\
\hline pMWsodA & pMW119-based plasmid carrying sodA & This study \\
\hline pMWsodB & pMW119-based plasmid carrying sodB & This study \\
\hline pMWsodAsodB & pMW119-based plasmid carrying sodA and sodB & This study \\
\hline pMC1403 & Cloning vector for the lacZ reporter system with the replication origin of $\mathrm{pMB1}, \mathrm{Amp}^{\mathrm{r}}$ & (Casadaban et al. 1980) \\
\hline pMCkatEp & pMC1403-based plasmid carrying the katE promoter region & This study \\
\hline pMCkatGp & pMC1403-based plasmid carrying the katG promoter region & This study \\
\hline pMCsodAp & pMC1403-based plasmid carrying the sodA promoter region & This study \\
\hline pMCsodBp & pMC1403-based plasmid carrying the soxB promoter region & This study \\
\hline
\end{tabular}

of kanamycin-resistance with BW25113 $\Delta \operatorname{sodA}$ and BW25113 $k$ katG as the donor, respectively. The $\mathrm{Km}^{\mathrm{R}}$ cas-

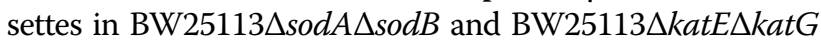
were also eliminated with pCP20. Elimination of the $\mathrm{Km}^{\mathrm{R}}$ cassette in the $\operatorname{sod} A$ and $k a t G$ region was confirmed by PCR analysis. The combination of primers for the $\operatorname{sod} A$ disruption was sodA-S and sodA-AS, and that for the $\Delta k a t G$ disruption was katG-S and katG-AS.

\section{Measurement of organic solvent-tolerance in E. coli} Cultures of $E$. coli strains in LBGMg medium after $16 \mathrm{~h}$ of incubation $\left(\mathrm{OD}_{660}, 4\right.$ to 5$)$ at $30{ }^{\circ} \mathrm{C}$ were diluted with 
Table 3 Primers used in this study

\begin{tabular}{|c|c|c|}
\hline Primer & Sequence $\left(5^{\prime}\right.$ to $\left.3^{\prime}\right)$ & Positions \\
\hline katE-S & TACTCAGTCACTTCCCCTTC & $426-445$ bp upstream of the initiation codon of katE \\
\hline katE-AS & AACTACGGCATTATCGAGGC & 934-953 bp downstream of the stop codon of katE \\
\hline katG-S & GGGGCAGATTAACGTTTCGT & $1141-1160$ bp upstream of the initiation codon of $\mathrm{kat} G$ \\
\hline katG-AS & GCCAGCACAATCAGCACAAT & 924-943 bp downstream of the stop codon of katG \\
\hline sodA-S & CGATGTTAGCGGCGACAATA & $1277-1296$ bp upstream of the initiation codon of sodA \\
\hline sodA-AS & GCTCTGGCTTTGACTTTACG & 1190-1209 bp downstream of the stop codon of sodA \\
\hline sodB-S & TTCGATCACGCTCTGTGCTT & 904-923 bp upstream of the initiation codon of sodB \\
\hline sodB-AS & TTAACTATCCGTTGCTGGCG & 1305-1324 bp downstream of the stop codon of sodB \\
\hline katEc-S & AAAGTCGACATTTGCCACGCAGCATCCAG & 311-330 bp upstream of the initiation codon of katE, Sall site underlined \\
\hline katEc-AS & TTTGGTACCAGGCCGGATAAGGCGTTCAC & 69-88 bp downstream of the stop codon of katE, Kpnl site underlined \\
\hline katGc-S & AAAGGTACCTTACGCGATTTGCCATACGC & 352-371 bp upstream of the initiation codon of $\mathrm{katG}, \mathrm{Kpnl}$ site underlined \\
\hline katGc-AS & TTTGAGCTCGTGTGTAGTTTTCGTTCGCC & 63-82 bp downstream of the stop codon of katG, Sacl site underlined \\
\hline sodAc-S & AAAGCATGCTAAAAACAGGCTGCACTGGC & 333-352 bp upstream of the initiation codon of sodA, Sphl site underlined \\
\hline sodAc-AS & TTTGTCGACTTTTTTAAAGCTGATATGCGGCC & 32-53 bp downstream of the stop codon of sodA, Sall site underlined \\
\hline sodBc-S & AAAGTCGACCTCTCAGTGAAGACTACTGG & 182-201 bp upstream of the initiation codon of sodB, Sall site underlined \\
\hline sodBc-AS & TTTGGATCCTGCCTTATCCGACCTACATC & 63-82 bp downstream of the stop codon of sodB, BamHI site underlined \\
\hline katEp-S & AAAGAATTCAACCGGGAGGTATGTAATCC & 446-466 bp upstream of the initiation codon of katE, EcoRI site underlined \\
\hline katEp-AS & TTTGGATCCTGCTGATGTGGGTTCTTTTCG & 15-35 bp downstream of the initiation codon of katE, BamHI site underlined \\
\hline katGp-S & AAACCCGGGCGAATATTGCCATGGATATGG & 439-459 bp upstream of the initiation codon of katG, Smal site underlined \\
\hline katGp-AS & TTTGGATCCGTGGTGTTATGGATATCGTCTG & 11-32 bp downstream of the initiation codon of $\mathrm{katG}, \mathrm{BamHI}$ site underlined \\
\hline sodAp-S & AAAGAATTCGCCCAGAAATTCGGTAGTAAC & 451-472 bp upstream of the initiation codon of sodA, EcoRl site underlined \\
\hline sodAp-AS & TTTGGATCCTCCAGGGCATCGTAAGCATACG & 26-47 bp downstream of the initiation codon of sodA, BamHI site underlined \\
\hline sodBp-S & AAAGAATTCGTACCGGTTTTGATTGCAGC & 434-453 bp upstream of the initiation codon of sodB, EcoRI site underlined \\
\hline sodBp-AS & TTTGGATCCGCCAGAGCATCTTTAGCATAT & $27-47$ bp downstream of the initiation codon of sodA, BamHI site underlined \\
\hline
\end{tabular}

$0.8 \%$ saline by serial tenfold dilutions. Five microliters of each suspension was spotted on LBGMg agar medium. The agar surface was overlaid with organic solvents (Tsukagoshi and Aono 2000). The formation of colonies on the agar was observed after $48 \mathrm{~h}$ of incubation at $25^{\circ} \mathrm{C}$.

\section{Cloning of the katE, katG, sodA and sodB genes}

The regions of katE, katG, $\operatorname{sod} A$ and $\operatorname{sodB}$ were amplified by PCR using AccuPrime Taq DNA Polymerase (Thermo Fisher Scientific Inc.) with high fidelity and BW25113 chromosomal DNA as the template. The primers used were designed according to the genome sequence of BW25113 deposited in GenBank (accession number CP009273). The combination of primers for $k a t E$ was katEc-S and katEc-AS, that for katG was katGc-S and katGc-AS, that for sodA was sodAc-S and sodAc-AS, and that for $\operatorname{sodB}$ was sodBc-S and sodBc-AS (Table 3). A restriction endonuclease cleavage site was introduced into all primer sequences. The amplified fragments were digested with the relevant restriction enzymes and ligated into the cloning site of pMW119 under the same direction as the lac promoter to construct plasmids pMWkatE, pMWkatG, pMWsodA, and pMWsodB, respectively. The pMWkatE was digested with KpnI and
SacI, and then the fragments containing kat $E$ were ligated between KpnI and SacI sites of pMWkatG. The resulting plasmid was designated pMWkatEkatG. In addition, the pMWsodA was digested with SphI and Sall, and then the fragments containing $\operatorname{sodA}$ were ligated between SphI and Sall sites of pMWsodB. The resulting plasmid was designated pMWsodAsodB.

\section{Enzyme activity assay}

E. coli cells grown in LBGMg medium after incubation at $30{ }^{\circ} \mathrm{C}$ for $16 \mathrm{~h}$ were harvested by centrifugation $(4400 \times g$ for $10 \mathrm{~min}$ at $4{ }^{\circ} \mathrm{C}$ ) and suspended in $10 \mathrm{mM}$ of Tris- $\mathrm{HCl}$ buffer ( $\mathrm{pH} 8.0)$. The cell suspension was sonicated on ice and centrifuged $\left(10,000 \times g, 10 \mathrm{~min}\right.$ at $\left.4{ }^{\circ} \mathrm{C}\right)$. The supernatant was used for the enzyme activity assay.

Catalase activity was determined by following the rate of $\mathrm{H}_{2} \mathrm{O}_{2}$ consumption at $240 \mathrm{~nm}$ (Claiborne et al. 1979). The enzyme activity was calculated from the molar adsorption coefficient of the $\mathrm{H}_{2} \mathrm{O}_{2}\left(\varepsilon=43.6 \mathrm{M}^{-1} \mathrm{~cm}^{-1}\right)$. The reaction mixture $(1 \mathrm{~mL})$ contained $50 \mathrm{mM}$ potassium phosphate buffer at $\mathrm{pH} 7.0$ and $10 \mathrm{mM} \mathrm{H}_{2} \mathrm{O}_{2}$. The reaction was initiated by adding the enzyme solution $(50 \mu \mathrm{L})$ to the reaction mixture and the initial velocity of $\mathrm{H}_{2} \mathrm{O}_{2}$ disappearance was measured at $30{ }^{\circ} \mathrm{C}$. One unit 
of enzyme activity was defined as the amount of enzyme that decomposes $1 \mu \mathrm{mol}$ of $\mathrm{H}_{2} \mathrm{O}_{2}$ per min.

SOD activity was measured by following the rate of pyrogallol autooxidation (Marklund and Marklund 1974). The enzyme solution $(10 \mu \mathrm{L})$ was mixed with $2.48 \mathrm{~mL}$ of $50 \mathrm{mM}$ Tris- $\mathrm{HCl}$ and $1 \mathrm{mM}$ EDTA at $\mathrm{pH}$ 8.2. After preincubation for $5 \mathrm{~min}$ at $25{ }^{\circ} \mathrm{C}$, the reaction was started by adding $10 \mu \mathrm{L}$ of $50 \mathrm{mM}$ pyrogallol solution in $10 \mathrm{mM}$ $\mathrm{HCl}$. The change of absorbance was monitored at $325 \mathrm{~nm}$. One unit of enzyme is defined as the amount of enzyme that inhibits the autoxidation rate of pyrogallol by $50 \%$.

\section{Protein content}

The protein concentration was determined by the method of Bradford (Bradford 1976) using bovine serum albumin as the standard.

\section{Sensitivities of $E$. coli strains to $\mathrm{H}_{2} \mathrm{O}_{2}$ and menadione}

E. coli cells grown in LBGMg medium $(10 \mathrm{~mL})$ at $37{ }^{\circ} \mathrm{C}$ to an $\mathrm{OD}_{660}$ of about 0.6 (approximately 4 to $5 \times 10^{8}$ cells $/ \mathrm{ml}$ ) were harvested by centrifugation $(4400 \times \mathrm{g}$ for $10 \mathrm{~min}$ at $\left.4{ }^{\circ} \mathrm{C}\right)$, and suspended in PBS buffer $(10 \mathrm{~mL})$ consisting of $140 \mathrm{mM} \mathrm{NaCl}, 8.1 \mathrm{mM} \mathrm{Na} 2 \mathrm{HPO}_{4}, 2.7 \mathrm{mM}$

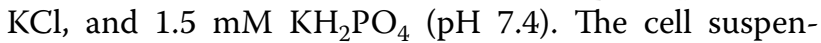
sion was washed once by centrifugation, resuspended in PBS buffer with $\mathrm{H}_{2} \mathrm{O}_{2}$ (1 to $4 \mathrm{mM}$ ) or menadione (15 to $60 \mathrm{mM}$ ), and further incubated with shaking at $37{ }^{\circ} \mathrm{C}$. After incubation for $1 \mathrm{~h}$, each suspension was plated on LB agar medium. The number of colonies formed on the agar plate was counted after $24 \mathrm{~h}$ of incubation at $30^{\circ} \mathrm{C}$.

\section{Detection of reactive oxygen species}

The ROS were detected with the 5-(and-6)-carboxy2,7'-dichlorodihydrofluorescein diacetate (carboxy$\mathrm{H}_{2}$ DCFDA) (Molecular Probes, Eugene, OR) as reported previously with a slight modification (Rutherford et al. 2010). Carboxy- $\mathrm{H}_{2}$ DCFDA is a cell-permeable indicator for ROS that does not fluoresce until it is hydrolyzed by esterases and oxidation occurs within cells. A $100 \mu \mathrm{l} \mathrm{cul-}$ ture of overnight-grown E. coli cells was inoculated onto $10 \mathrm{ml}$ of fresh LBGMg medium and incubated at $37{ }^{\circ} \mathrm{C}$ with shaking. After incubation for $3 \mathrm{~h}, 0.5 \mathrm{~mL}$ of $7.78 \mathrm{M}$ tert-butyl hydroperoxide (TBHP; used as a positive control for oxidative stress) or $1 \mathrm{~mL}$ of an organic solvent ( $n$-hexane or cyclohexane) was added to the culture. The culture was further incubated at $37^{\circ} \mathrm{C}$ for $3 \mathrm{~h}$ with shaking. Twenty microliters of each culture was added to $1 \mathrm{ml}$ of M9 medium. After incubation at $37{ }^{\circ} \mathrm{C}$ for $45 \mathrm{~min}$, $50 \mu \mathrm{l}$ of $25 \mathrm{mM}$ carboxy- $\mathrm{H}_{2}$ DCFDA samples was added to the medium. After incubation at $37{ }^{\circ} \mathrm{C}$ for $10 \mathrm{~min}$, the $\mathrm{OD}_{660}$ and the fluorescence excitation/emission at $485 / 535 \mathrm{~nm}$ of each sample were measured by spectrofluorometer (RF-6000; Shimadzu Co., Kyoto, Japan).
Specific fluorescence was calculated as fluorescence/ $\mathrm{OD}_{660}$.

\section{Construction of the lacZ reporter fusions}

The promoter regions of $k a t E, k a t G$, $\operatorname{sod} A$ and $\operatorname{sodB}$ were amplified by PCR using AccuPrime Taq DNA Polymerase and BW25113 chromosomal DNA as the template. The combination of primers for the $k a t E$ promoter region was katEp-S and katEp-AS, that for the $k a t G$ promoter region was katGp-S and katGp-AS, that for the $\operatorname{sodA}$ promoter region was sodAp-S and sodAp-AS, and that for the $\operatorname{sodB}$ promoter region was sodBp-S and sodBp-AS (Table 3 ). The amplified fragments were digested with the relevant restriction enzymes and ligated into the cloning site of pMC1403 to construct plasmids pMCkatEp, pMCkatGp, pMCsodAp, and pMCsodBp, respectively.

\section{Assay for plasmid-borne $\beta$-galactosidase activity}

E. coli strains were grown in LBGMg containing $50 \mu \mathrm{g} /$ $\mathrm{ml}$ ampicillin at $37^{\circ} \mathrm{C}$. Cells in the exponential phase of growth were treated with a small volume of chloroform and assayed for $\beta$-galactosidase activity as described previously (Miller 1972).

\section{Results}

\section{Organic solvent-tolerances of $E$. coli mutants deficient} in ROS-scavenging enzymes

The colony-forming efficiency of the BW25113based $\Delta k a t E, \Delta k a t G, \Delta a h p F, \Delta \operatorname{sod} A, \Delta \operatorname{sodB}, \Delta \operatorname{sod} C$, $\Delta k a t E \Delta k a t G$ and $\Delta \operatorname{sod} A \Delta \operatorname{sodB}$ mutants was investigated using an LBGMg agar plate in the presence of $n$-hexane (Fig. 1). All strains formed colonies in all spots on the plate without any solvent. The colony-forming

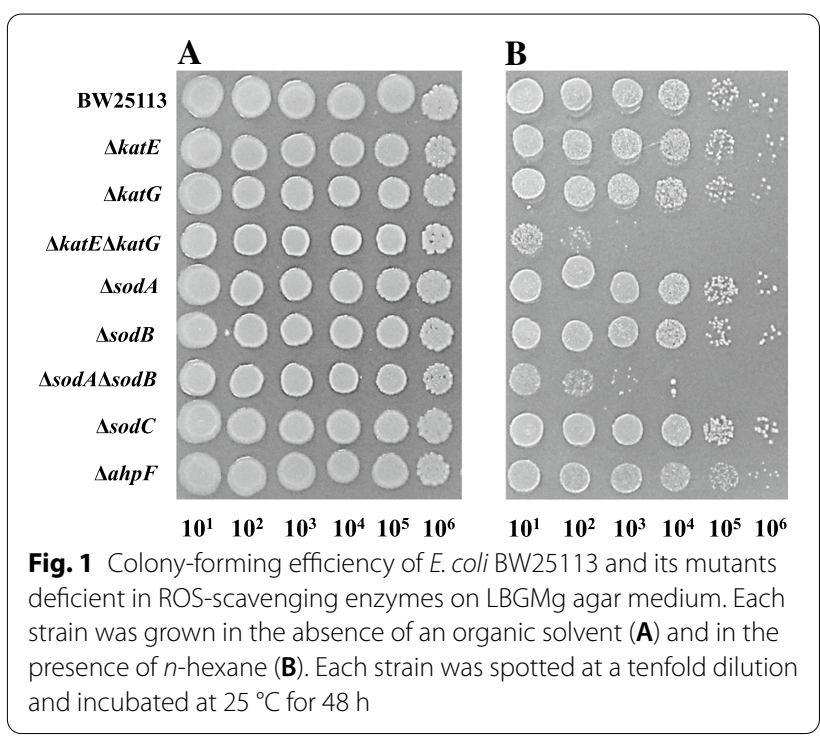


efficiencies in the single gene mutants were similar to that in the parent strain BW25113 in the presence of $n$-hexane. In contrast, the double gene mutants, BW25113 $\Delta$ katE $\Delta k a t G$ and BW25113 ssodA $\Delta \operatorname{sodB}$, were highly sensitive to $n$-hexane, exhibiting $10^{2}$ - or $10^{3}$-fold lower colony-forming efficiencies than the parent strain in the presence of the solvent. These results indicated that catalase and SOD were involved in the maintenance of organic solvent-tolerance in E. coli.

Complementation of organic solvent-tolerances of BW25 $113 \Delta k a t E \Delta k a t G$ and BW25113 ssodA $\Delta$ sodB by transformation of the catalase- or SOD-coding gene was investigated(Fig. 2). The colony-forming efficiencies in BW25113 $k$ katE $k \mathrm{ka}$ $t G$ (pMWkatE), BW25113 $\Delta$ katE $\Delta k a t G$ (pMWkatG), and

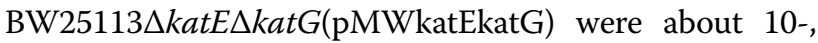
$10^{2}$-, and $10^{3}$-fold higher than that in BW25113(pMW119) in the presence of $n$-hexane, respectively. On the other hand, the colony-forming efficiencies in BW25113A $\operatorname{sod} A \triangle \operatorname{sod} B(\mathrm{pMW}$ sodA) and BW25113 $\Delta \operatorname{sod} A \Delta \operatorname{sod} B(\mathrm{pMW}$ sodB) were both about tenfold higher than that in BW25 113(pMW119). In addition, the efficiency in BW25113 $\triangle \operatorname{sod} A \Delta \operatorname{sodB}\left(\mathrm{pMW}\right.$ SodAsodB) was about $10^{3}$-fold higher than that in BW25113(pMW119). Thus, it was shown that $k a t E$, $k a t G, \operatorname{sod} A$, and $\operatorname{sod} B$ genes contribute to the maintenance of $n$-hexane-tolerance in $E$. coli.

\section{Activities of ROS-scavenging enzymes and susceptibility to $\mathrm{H}_{2} \mathrm{O}_{2}$ and menadione in $\mathrm{BW} 25113 \Delta$ katE $\Delta$ kat $G$ and BW25113 $\Delta$ sodALsodB}

The levels of catalase and SOD activities in BW25113 $\Delta k a t E \Delta k a t G$ and BW25113 $\Delta$ sodA $\Delta$ sodB were compared with the parent strain BW25113 (Table 4). Most of the catalase and SOD activities were eliminated

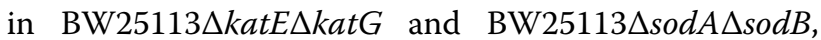

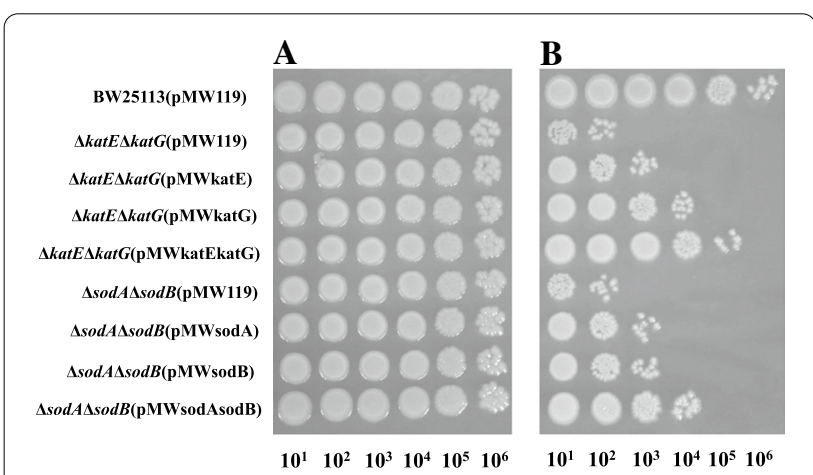

Fig. 2 Colony-forming efficiency of BW25113-based recombinant E. coli strains. Each strain was grown on LBGMg agar medium containing ampicillin $(50 \mu \mathrm{g} / \mathrm{ml})$ and isopropyl- $\beta$-D-thiogalactopyra noside (IPTG; $0.5 \mathrm{mM}$ ) in the absence of an organic solvent $(\mathbf{A})$ and in the presence of $n$-hexane (B). Each strain was spotted at a tenfold dilution and incubated at $25^{\circ} \mathrm{C}$ for $48 \mathrm{~h}$
Table 4 Catalase and SOD activities of E. coli strains

\begin{tabular}{|c|c|c|}
\hline \multirow[t]{2}{*}{ Strain } & \multicolumn{2}{|c|}{ Enzymatic activity } \\
\hline & Catalase (U/mg) & $\mathrm{SOD}(\mathrm{U} / \mathrm{mg})$ \\
\hline BW25113 & $1.41 \pm 0.07$ & $0.18 \pm 0.01$ \\
\hline BW25113 $\Delta$ katE $\Delta k a t G$ & $0.06 \pm 0.07$ & $0.20 \pm 0.03$ \\
\hline BW25113 $\triangle \operatorname{sod} A \triangle \operatorname{sod} B$ & $1.55 \pm 0.15$ & $0.01 \pm 0.01$ \\
\hline
\end{tabular}

Data represent the mean $\pm S D$ of triplicate experiments

respectively. The slight remaining activities of catalase and SOD seemed to be attributable to AhpCF and SodC, respectively. These results showed good agreement with a previous report (Alhama et al. 1998).

Susceptibility of the mutants to ROS was also confirmed by measuring the cell viability after exposure to $\mathrm{H}_{2} \mathrm{O}_{2}$ and a redox-cycling agent, menadione (Additional file 1: Fig. S1). The survival fraction of BW25113 $\Delta$ katE $\Delta$ katG in $4 \mathrm{mM} \mathrm{H}_{2} \mathrm{O}_{2}$ and BW25113 $\Delta \operatorname{sod} A \Delta \operatorname{sodB}$ in $60 \mathrm{mM}$ menadione were $40 \%$ and $0.3 \%$ of those of the parent strain BW25113, respectively.

\section{Growth of the $E$. coli mutants in liquid medium in the presence of organic solvents}

The cell growth of BW25113, BW25113 $k$ katE $\Delta k a t G$ and BW25113 $\triangle \operatorname{sod} A \triangle \operatorname{sodB}$ in the LBGMg liquid medium in the presence of a hydrophobic solvent including cyclooctane, $n$-hexane, or a hydrophobic solvent mixture of $n$-hexane and cyclohexane $(9: 1 \mathrm{vol} / \mathrm{vol})$ was examined by measuring the turbidity (Fig. 3). In the absence of the solvent, the specific growth rates of BW25113,

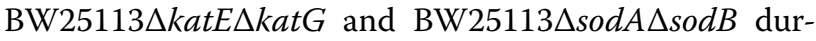
ing the exponential growth phase were $1.6 \mathrm{~h}^{-1}, 1.5 \mathrm{~h}^{-1}$ and $1.3 \mathrm{~h}^{-1}$, respectively. In the presence of cyclooctane,

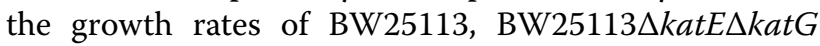
and BW25113 $\Delta \operatorname{sod} A \Delta \operatorname{sodB}$ were $1.5 \mathrm{~h}^{-1}, 1.2 \mathrm{~h}^{-1}$ and $1.0 \mathrm{~h}^{-1}$, respectively. Thus, the growth of these mutants without any organic solvents and in the presence of cyclooctane was slower than that of the parent strain BW25113. The growth of BW25113 $\Delta$ katE $\Delta k a t G$ and BW25113 $\triangle \operatorname{sod} A \Delta \operatorname{sodB}$ was highly suppressed compared to that of BW25113 in the presence of $n$-hexane or the mixture of $n$-hexane and cyclohexane. These results suggested that each of catalase and SOD is involved in the maintenance of tolerance to hydrophobic organic solvents. BW25113 $\Delta \operatorname{sod} A \Delta \operatorname{sodB}$ exhibited an extended lag phase and BW25113 $k$ katE $\Delta$ katG did not grow during $8 \mathrm{~h}$ cultivation in the presence of $n$-hexane. Thus, BW25113 $\Delta$ katE $\Delta$ katG was more sensitive to $n$-hexane than BW25113 $\Delta$ sodA $\Delta s o d B$. 


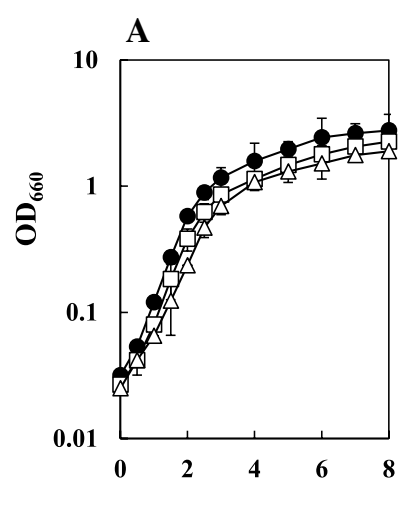

Time (h)

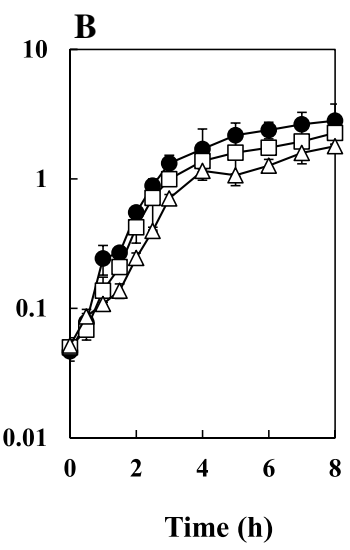

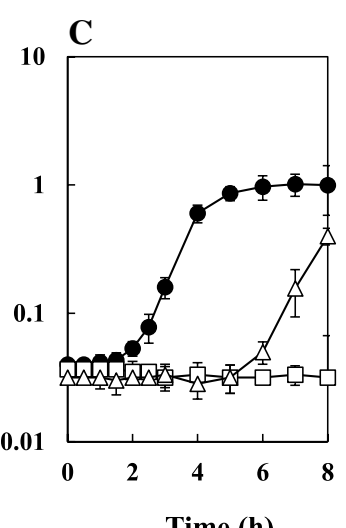

Time (h)

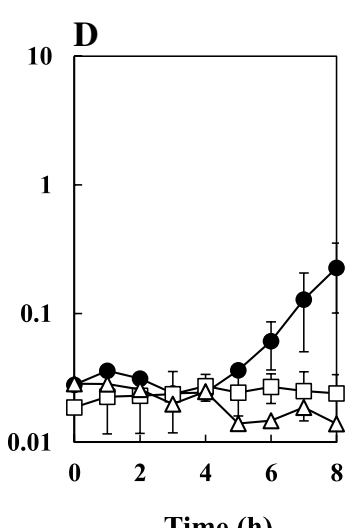

Time (h)

Fig. 3 Growth of E. coli BW25113, BW25113 $\triangle$ katE $\triangle k a t G$ and BW25113 $\triangle$ sodA $\triangle$ sodB in LBGMg liquid medium at $37^{\circ} \mathrm{C}$ in the absence of an organic solvent $(\mathbf{A})$ and in the presence of 10\% (vol/vol) cyclooctane (B), 10\% (vol/vol) $n$-hexane (C), or a 10\% (vol/vol) $n$-hexane and cyclohexane mixture (9:1 vol/vol) (D). A 100- $\mu \mathrm{l}$ culture of an overnight-grown E. coli strain was inoculated into $10 \mathrm{ml}$ of fresh LBGMg liquid medium containing an organic solvent. This two-phase culture was incubated at $37^{\circ} \mathrm{C}$. Growth was monitored by measuring turbidity $\left(\mathrm{OD}_{660}\right)$. Symbols: filled circle, BW25113;

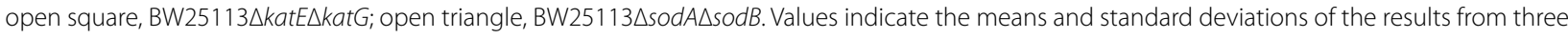
independent experiments

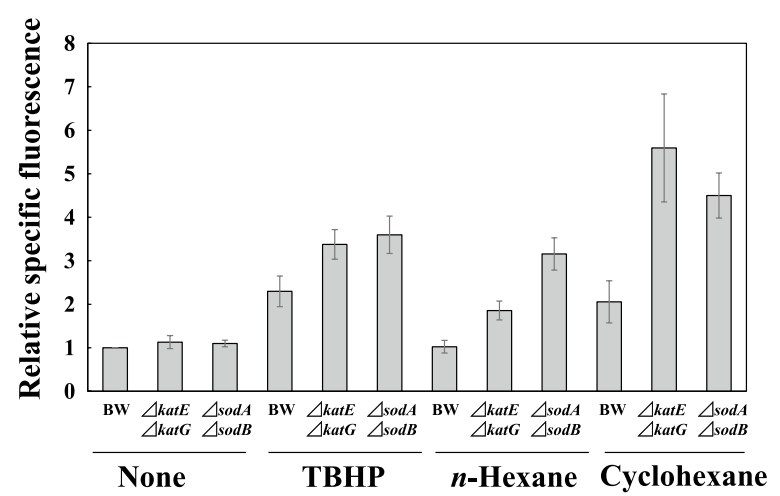

Fig. 4 Levels of intracellular ROS in E. coli cells measured by using carboxy- $\mathrm{H}_{2}$ DCFDA. ROS levels were measured in the strains exposed to TBHP (tert-butyl hydroperoxide), $n$-hexane or cyclohexane as described in the Methods. The relative specific fluorescence shows the ratio of the specific fluorescence in each strain divided by that in strain BW25113 not exposed to the organic solvent. Abbreviations: BW, BW25113; $\triangle k a t E \Delta k a t G$, BW25113 $\Delta k a t E \Delta k a t G ; ~ \triangle s o d A \Delta s o d B$, BW25113 $\triangle$ sodA $\triangle$ sodB. Mean values and standard deviations for three independent experiments are shown

\section{Detection of ROS in E. coli cells exposed to hydrophobic organic solvents}

We examined the ROS levels in BW25113,

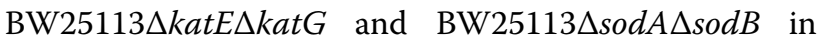
the presence of $n$-hexane or cyclohexane with carboxy$\mathrm{H}_{2}$ DCFDA, a fluorescent indicator for ROS in cells (Fig. 4). No significant difference in ROS levels was observed among these three strains in the absence of TBHP (a known inducer for ROS) or organic solvents. Addition of TBHP enhanced the ROS levels in these three strains. Treatment with $n$-hexane had little impact on ROS levels in BW25113 but markedly elevated ROS levels in BW25113 $\Delta k a t E \Delta k a t G$ and BW25113 $\Delta$ sodA $\Delta \operatorname{sodB}$. The ROS levels by exposure to $n$-hexane in BW25113 $\Delta$ katE $\Delta k a t G$ and BW25113 $\Delta \operatorname{sod} A \Delta \operatorname{sodB}$ were 1.9- and 3.2-fold higher than that in BW25113, respectively. Cyclohexane-exposure significantly increased ROS levels in all strains. The ROS levels by expo-

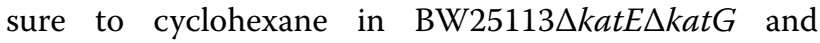
BW25113 $\triangle \operatorname{sod} A \triangle \operatorname{sodB}$ were 2.8- and 2.3-fold higher than that in BW25113, respectively. The ROS levels in the three strains by the addition of cyclohexane were higher than those by addition of $n$-hexane, respectively.

\section{Induction of katE, katG, sodA and sodB by $n$-hexane}

We constructed plasmids pMCkatEp, pMCkatGp, pMCsodAp and pMCsodBp containing katE-lacZ, katG-lacZ, $\operatorname{sod} A-l a c Z$, and $\operatorname{sod} B-l a c Z$-fused genes, respectively. BW25113 harboring one of the plasmids was assayed for plasmid-borne $\beta$-galactosidase activity (Fig. 5). Promoter activities of katE, katG, soda, and $\operatorname{sodB}$ with $n$-hexane were 1.2-, 1.3-, 3.9-, and 2.6-fold compared to those without any solvent, respectively. In particular, the promoter activities of $\operatorname{sod} A$ and $\operatorname{sod} B$ were significantly increased by exposure to $n$-hexane.

\section{Discussion}

The cell membrane is the main target of organic solvents (Aono et al. 1994). The cytoplasmic membrane of bacterial cells plays a crucial role in various cell functions such as regulation of solutes (nutrients and ions) passage, energy generation, synthesis of membrane lipids and cell 

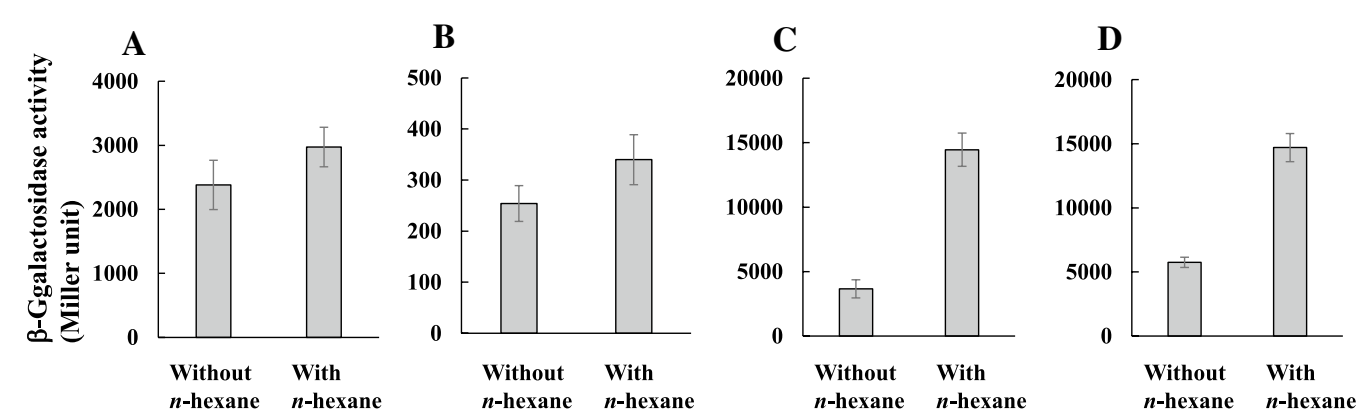

Fig. 5 Effect of $n$-hexane on the promoter activity of katE, katG, sodA, or sodB. A 100- $\mu$ culture of the overnight-grown strain BW25113(pMCkatEp) (A), BW25113(pMCkatGp) (B), BW25113(pMCsodAp) (C), or BW25113(pMCsodBp) (D) was inoculated into 10 ml of fresh LBGMg liquid medium containing $50 \mathrm{\mu g} / \mathrm{ml}$ ampicillin without or with $1 \mathrm{ml}$ of $n$-hexane. The culture was incubated at $37^{\circ} \mathrm{C}$ until reaching an $\mathrm{OD}_{600}$ of approximately 0.6 . Cells were treated with chloroform and assayed for $\beta$-galactosidase activity. Values indicate the means and standard deviations of the results from three independent experiments

wall, secretion of extracytoplasmic proteins, and turgor pressure. Organic solvent molecules intercalate into the lipid bilayer of the membrane. Accumulation of organic solvent in the membrane disturbs a variety of vital cell processes, including those described above. The inner membrane in E. coli contains an electron transport chain that is the major site of the premature electron leakage to oxygen that generates superoxide $\left(\mathrm{O}_{2}{ }^{-}\right)$. Disturbance of the electron transport chain by organic solvent can increase the level of ROS. ROS have the capacity to damage various biomolecules, including proteins, ribosomes and DNA, and to reduce cellular culturability (Imlay 2003).

In the present study, we investigated the involvement of ROS-scavenging enzymes in hydrophobic organic solvent-tolerance. The colony-forming efficiency of $E$. coli strains on LBGMg agar showed that the tolerances to $n$-hexane in single gene-knockout mutants lacking the katE, katG, ahpF, sodA, sodB, or $\operatorname{sod} C$ gene were similar to that in the parent strain BW25113 (Fig. 1). AhpF is the peroxiredoxin reductase component of alkyl hydroperoxide reductase (AhpCF) that has been reported to be involved in tolerance to organic solvents such as 1,2,3,4-tetrahydronaphthalene (tetralin), cyclohexane, propylbenzene, and 1,2-dihydronaphthalene (Ferrante et al. 1995). AhpF and AhpC proteins act together (Li Calzi and Poole 1997). AhpF utilizes NADH or NADPH as electron donor to AhpC, which converts alkylhydroperoxides to their respective alcohol forms. AhpC is specifically reduced by $\mathrm{AhpF}$ and cannot be reduced by other electron transfer systems such as thioredoxin reductase. However, our results showed that deficiency of $a h p F$ did not influence the tolerance to $n$-hexane. It has been reported that a $\operatorname{sod} A \operatorname{sod} B$ double mutant was much more sensitive to paraquat than the wild type, although the absence of only the $\operatorname{sod} A$ gene or only the $\operatorname{sod} B$ gene had no effect on the sensitivity to paraquat (a superoxide generator) (Carlioz and Touati 1986). Both the $\operatorname{sod} A$ sodB double mutant and katE katG double mutant were more sensitive to $p$-nonylphenol (an endocrine disruptor) than the parent strain (Okai et al. 2004). In particular, the $\operatorname{sod} A \operatorname{sod} B$ double mutant was highly sensitive to $p$-nonylphenol. These findings prompted us to construct BW25113 $\Delta k a t E \Delta k a t G$ and BW25113 $\operatorname{sod} A \Delta \operatorname{sodB}$ and then examine their organic solvent-tolerances. BW25113 $\Delta k a t E \Delta k a t G$ and BW25113 $\operatorname{sod} A \Delta \operatorname{sodB}$ lost most of their catalase and SOD activities, respectively (Table 4). In addition, we confirmed that

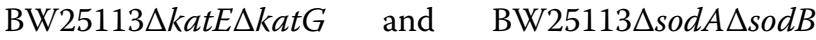
became sensitive to $\mathrm{H}_{2} \mathrm{O}_{2}$ and menadione (an $\mathrm{O}_{2}{ }^{-}$generator), respectively (Additional file 1: Fig. S1). Both BW25113 $\Delta$ katE $\Delta k a t G$ and BW25113 $\Delta \operatorname{sod} A \Delta \operatorname{sodB}$ were highly sensitive to $n$-hexane and a mixture of $n$-hexane and cyclohexane (Figs. 1 and 3). These results showed that accumulation of either $\mathrm{H}_{2} \mathrm{O}_{2}$ or $\mathrm{O}_{2}{ }^{-}$in E. coli can exhibit an inhibitory effect on the cell growth. $\mathrm{H}_{2} \mathrm{O}_{2}$ and $\mathrm{O}_{2}{ }^{-}$are relatively weak cytotoxic radical oxygens compared to other radical oxygens such as hydroxyl radicals (Bruno-Barcena et al. 2010; Fridovich 1986). Therefore, the hydroxyl radical produced via Fenton reaction and Haber-Weiss reaction from $\mathrm{H}_{2} \mathrm{O}_{2}$ and $\mathrm{O}_{2}{ }^{-}$might be a main cause of the cytotoxicity by addition of hydrophobic organic solvents. Our assays using the fluorescent probe carboxy- $\mathrm{H}_{2}$ DCFDA showed an increase in ROS after solvent stress (Fig. 4). In addition, the ROS levels in E. coli cells induced by exposure to cyclohexane were higher than those observed by exposure to $n$-hexane. Thus, the ROS level in E. coli cells is likely to depend on the amount of organic solvents accumulated in the cells, since a larger amount of cyclohexane than $n$-hexane is accumulated in cells in an organic-aqueous two-liquid-phase system (Tsukagoshi and Aono 2000). 
We found that the promoter activities of $\operatorname{sod} A$ and $\operatorname{sod} B$ were significantly increased by $n$-hexane (Fig. 5 ). Expression of SodA is regulated by several global transcription regulators, including the MarA/SoxS/Rob system and Fur (Ferric uptake regulator), and responds to changes in oxygen concentration, redox active compounds, and iron concentration (Fee 1991; Semsey 2014). SodB levels were relatively insensitive to changes in these conditions. SodB seems to be responsible for protection of a cytoplasmic superoxide-sensitive enzyme, while SodA is more effective in preventing DNA damage (Hopkin et al. 1992). Oxidative stress response genes in bacteria are often upregulated during exposure to solvents. The sodA gene in E. coli strains was upregulated by ethanolor $n$-butanol-induced stress (Cao et al. 2017; Rutherford et al. 2010). Antioxidant enzymes such as catalase and superoxide dismutase in Pseudomonas putida showed increased activity upon exposure to toluene (Choi et al. 2014).

In this study, we showed that ROS-scavenging enzymes significantly contributed to the maintenance of tolerance to hydrophobic organic solvents in E. coli. Various mechanisms of organic solvent-tolerance in $E$. coli have been reported so far. These include the multidrug efflux pump (Tsukagoshi and Aono 2000; Watanabe and Doukyu 2012, 2014), maintenance of the proton motive force (Kobayashi et al. 1998), lipopolysaccharides (Abe et al. 2003), fatty acids synthesis (Oh et al. 2012), metabolic pathway for carbon catabolism (Shimizu et al. 2005), reduction of alkylhydroperoxide (Ferrante et al. 1995) and osmoprotectant transport (Doukyu et al. 2012). However, the involvement of catalase and SOD in hydrophobic organic solvent tolerance in E. coli has not been reported so far. Thus, the present study provides valuable new knowledge of the organic solvent-tolerance mechanisms in E. coli.

\section{Abbreviations}

ROS: Reactive oxygen species; SOD: Superoxide dismutase; HP: Hydroperoxidase; Carboxy-H 2 DCFDA: 5-(And-6)-carboxy-2,'7'-dichlorodihydrofluorescein diacetate; Km: Kanamycin; EDTA: Ethylenediaminetetraacetic acid; TBHP: tertButyl hydroperoxide.

\section{Supplementary Information}

The online version contains supplementary material available at https://doi. org/10.1186/s13568-021-01258-w.

Additional file 1: Figure S1. Effects of $\mathrm{H}_{2} \mathrm{O}_{2}$ and menadione on the cell viability of E. coli BW25113 and its mutants deficient in ROS-scavenging enzymes. Each strain was exposed to $\mathrm{H}_{2} \mathrm{O}_{2}(\mathrm{~A})$ and menadione (B). After incubation with $\mathrm{H}_{2} \mathrm{O}_{2}$ and menadione for $1 \mathrm{~h}$, viable cells were measured by examining the formation of colonies on LB agar medium. The survival fraction was calculated as the number of colonies treated with $\mathrm{H}_{2} \mathrm{O}_{2}$ or menadione divided by that of untreated cells. Symbols: filled

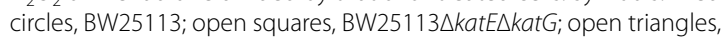

BW25113 $\triangle$ sodA $\triangle$ sodB. Values indicate the means and standard deviations of the results from three independent experiments.

\section{Acknowledgements}

The authors thank Masahiro Kawano and Kenta Ozaki for their technical assistance.

\section{Authors' contributions}

ND designed the experiments and wrote the paper; ND and KT performed the experiments and analyzed the data. All authors read and approved the final manuscript.

\section{Funding}

This work was supported in part by a Grant-in-Aid for Scientific Research (C) 17 K07731 from the Japan Society for the Promotion of Science (JSPS), by a Grant for the Programme for the Strategic Research Foundation at Private Universities S1 101017, organized by the Ministry of Education, Culture, Sports, Science and Technology (MEXT), Japan, and by a Grant for the Toyo University Priority Research Promotion Program.

\section{Availability of data and materials}

All discussed data have been included into the manuscript or in the Additional file 1. Please turn to the corresponding author for all other requests.

\section{Declarations}

Ethics approval and consent to participate Not applicable.

\section{Consent for publication}

Not applicable.

\section{Competing interests}

The authors declare that they have no competing interests.

\section{Author details}

${ }^{1}$ Department of Life Science, Toyo University, 1-1-1 Izumino, Itakura-machi, Gunma 374-0193, Japan. ${ }^{2}$ Bio-Nano Electronic Research Center, Toyo University, 2100, Kujirai, Kawagoe, Saitama 350-8585, Japan.

Received: 18 May 2021 Accepted: 16 June 2021

Published online: 29 June 2021

\section{References}

Abe S, Okutsu T, Nakajima H, Kakuda N, Ohtsu I, Aono R (2003) n-Hexane sensitivity of Escherichia coli due to low expression of imp/ostA encoding an $87 \mathrm{kDa}$ minor protein associated with the outer membrane. Microbiology 149(Pt 5):1265-1273. https://doi.org/10.1099/mic.0.25927-0

Akhtar MK, Dandapani H, Thiel K, Jones PR (2015) Microbial production of 1-octanol: a naturally excreted biofuel with diesel-like properties. Metab Eng Commun 2:1-5. https://doi.org/10.1016/j.meteno.2014.11.001

Alhama J, Ruiz-Laguna J, Rodriguez-Ariza A, Toribio F, Lopez-Barea J, Pueyo C (1998) Formation of 8-oxoguanine in cellular DNA of Escherichia coli strains defective in different antioxidant defences. Mutagenesis 13(6):589-594. https://doi.org/10.1093/mutage/13.6.589

Aono R (1998) Improvement of organic solvent tolerance level of Escherichia coli by overexpression of stress-responsive genes. Extremophiles 2(3):239-248. https://doi.org/10.1007/s007920050066

Aono R, Aibe K, Inoue A, Horikoshi K (1991) Preparation of organic solventtolerant mutants from Escherichia coli K-12. Agric Biol Chem 55(7):19351938. https://doi.org/10.1080/00021369.1991.10870883

Aono R, Kobayashi H, Joblin KN, Horikoshi K (1994) Effects of organic solvents on growth of Escherichia coli K-12. Biosci Biotechnol Biochem 58(11):2009-2014. https://doi.org/10.1271/bbb.58.2009

Baba T, Ara T, Hasegawa M, Takai Y, Okumura Y, Baba M, Datsenko KA, Tomita M, Wanner BL, Mori H (2006) Construction of Escherichia coli K-12 in-frame, 
single-gene knockout mutants: the Keio collection. Mol Syst Biol 2(2006):0008. https://doi.org/10.1038/msb4100050

Bradford MM (1976) A rapid and sensitive method for the quantitation of microgram quantities of protein utilizing the principle of protein-dye binding. Anal Biochemi 72(1):248-254. https://doi.org/10.1016/00032697(76)90527-3

Bruno-Barcena JM, Azcarate-Peril MA, Hassan HM (2010) Role of antioxidant enzymes in bacterial resistance to organic acids. Appl Environ Microbiol 76(9):2747-2753. https://doi.org/10.1128/aem.02718-09

Cao H, Wei D, Yang Y, Shang Y, Li G, Zhou Y, Ma Q, Xu Y (2017) Systems-level understanding of ethanol-induced stresses and adaptation in E. coli. Sci Rep 7:44150. https://doi.org/10.1038/srep44150

Carlioz A, Touati D (1986) Isolation of superoxide dismutase mutants in Escherichia coli: is superoxide dismutase necessary for aerobic life? EMBO J 5(3):623-630. https://doi.org/10.1002/j.1460-2075.1986.tb04256.x

Casadaban MJ, Chou J, Cohen SN (1980) In vitro gene fusions that join an enzymatically active beta-galactosidase segment to amino-terminal fragments of exogenous proteins: Escherichia coli plasmid vectors for the detection and cloning of translational initiation signals. J Bacteriol 143(2):971. https://doi.org/10.1128/JB.143.2.971-980.1980

Cherepanov PP, Wackernagel W (1995) Gene disruption in Escherichia coli: $\mathrm{TC}^{\mathrm{R}}$ and $\mathrm{Km}^{\mathrm{R}}$ cassettes with the option of Flp-catalyzed excision of the antibiotic-resistance determinant. Gene 158(1):9-14. https://doi.org/10. 1016/0378-1119(95)00193-A

Chin W-C, Lin K-H, Chang J-J, Huang C-C (2013) Improvement of $n$-butanol tolerance in Escherichia coli by membrane-targeted tilapia metallothionein. Biotechnol Biofuels 6(1):130. https://doi.org/10.1186/1754-6834-6-130

Choi HJ, Yoo J-S, Jeong YK, Joo WH (2014) Involvement of antioxidant defense system in solvent tolerance of Pseudomonas putida BCNU 106. J Basic Microbiol 54(9):945-950. https://doi.org/10.1002/jobm.201300176

Claiborne A, Malinowski DP, Fridovich I (1979) Purification and characterization of hydroperoxidase II of Escherichia coli B. J Biol Chem 254(22):1 166411668. https://doi.org/10.1016/S0021-9258(19)86535-3

Doukyu N, Toyoda K, Aono R (2003) Indigo production by Escherichia coli carrying the phenol hydroxylase gene from Acinetobacter sp. strain ST-550 in a water-organic solvent two-phase system. Appl Microbiol Biotechnol 60(6):720-725. https://doi.org/10.1007/s00253-002-1187-1

Doukyu N, Ishikawa K, Watanabe R, Ogino H (2012) Improvement in organic solvent tolerance by double disruptions of proV and marR genes in Escherichia coli. J Appl Microbiol 112(3):464-474. https://doi.org/10. 1111/j.1365-2672.2012.05236.x

Doukyu N, lida S (2020) Production of styrene oxide from styrene by a recombinant Escherichia coli with enhanced AcrAB-TolC efflux pump level in an aqueous-organic solvent two-phase system. Biosci Biotechnol Biochem 84(7):1513-1520. https://doi.org/10.1080/09168451.2020.1755219

Fee JA (1991) Regulation of sod genes in Escherichia coli: relevance to superoxide dismutase function. Mol Microbiol 5(11):2599-2610. https://doi.org/ 10.1111/j.1365-2958.1991.tb01968.x

Ferrante AA, Augliera J, Lewis K, Klibanov AM (1995) Cloning of an organic solvent-resistance gene in Escherichia coli: the unexpected role of alkylhydroperoxide reductase. Proc Natl Acad Sci U S A 92(17):7617-7621. https://doi.org/10.1073/pnas.92.17.7617

Fridovich I (1986) Biological effects of the superoxide radical. Arch Biochem Biophys 247(1):1-11. https://doi.org/10.1016/0003-9861(86)90526-6

Gort Amy S, Ferber Daniel M, Imlay James A (2002) The regulation and role of the periplasmic copper, zinc superoxide dismutase of Escherichia coli. Mol Microbiol 32(1):179-191. https://doi.org/10.1046/j.1365-2958.1999. 01343.x

Griepernau B, Leis S, Schneider MF, Sikor M, Steppich D, Bockmann RA (2007) 1-Alkanols and membranes: a story of attraction. Biochim Biophys Acta 1768(11):2899-2913. https://doi.org/10.1016/j.bbamem.2007.08.002

Heipieper HJ, Neumann G, Cornelissen S, Meinhardt F (2007) Solvent-tolerant bacteria for biotransformations in two-phase fermentation systems. Appl Microbiol Biotechnol 74(5):961-973. https://doi.org/10.1007/ s00253-006-0833-4

Hopkin KA, Papazian MA, Steinman HM (1992) Functional differences between manganese and iron superoxide dismutases in Escherichia coli K-12. J Biol Chem 267(34):24253-24258. https://doi.org/10.1016/S0021-9258(18) $35758-2$

Imlay JA (2003) Pathways of oxidative damage. Annu Rev Microbiol 57(1):395418. https://doi.org/10.1146/annurev.micro.57.030502.090938
Imlay JA, Linn S (1987) Mutagenesis and stress responses induced in Escherichia coli by hydrogen peroxide. J Bacteriol 169(7):2967-2976. https://doi. org/10.1128/jb.169.7.2967-2976.1987

Imlay KR, Imlay JA (1996) Cloning and analysis of sodC, encoding the copperzinc superoxide dismutase of Escherichia coli. J Bacteriol 178(9):25642571. https://doi.org/10.1128/jb.178.9.2564-2571.1996

Inoue A, Horikoshi K (1989) A Pseudomonas thrives in high concentrations of toluene. Nature 338:264. https://doi.org/10.1038/338264a0

Kabelitz N, Santos PM, Heipieper HJ (2003) Effect of aliphatic alcohols on growth and degree of saturation of membrane lipids in Acinetobacter calcoaceticus. FEMS Microbiol Lett 220(2):223-227. https://doi.org/10. 1016/50378-1097(03)00103-4

Kobayashi H, Yamamoto M, Aono R (1998) Appearance of a stress-response protein, phage-shock protein A, in Escherichia coli exposed to hydrophobic organic solvents. Microbiology 144(Pt 2):353-359. https://doi.org/10. 1099/00221287-144-2-353

Lennen RM, Politz MG, Kruziki MA, Pfleger BF (2013) Identification of transport proteins involved in free fatty acid efflux in Escherichia coli. J Bacteriol 195(1):135-144. https://doi.org/10.1128/JB.01477-12

Li Calzi M, Poole LB (1997) Requirement for the two AhpF cystine disulfide centers in catalysis of peroxide reduction by alkyl hydroperoxide reductase. Biochemistry 36(43):13357-13364. https://doi.org/10.1021/bi971 3660

Marklund S, Marklund G (1974) Involvement of the superoxide anion radical in the autoxidation of pyrogallol and a convenient assay for superoxide dismutase. Eur J Biochem 47(3):469-474. https://doi.org/10.1111/j.14321033.1974.tb03714.x

Miller JH (1972) Experiments in molecular genetics. ColdSpring Harbor Laboratory, Cold Spring Harbor, NY; pp. 352-355.

Mukhopadhyay A (2015) Tolerance engineering in bacteria for the production of advanced biofuels and chemicals. Trends Microbiol 23(8):498-508. https://doi.org/10.1016/j.tim.2015.04.008

Mulvey MR, Sorby PA, Triggs-Raine BL, Loewen PC (1988) Cloning and physical characterization of katE and katF required for catalase HPII expression in Escherichia coli. Gene 73(2):337-345. https://doi.org/10.1016/03781119(88)90498-2

Mukhopadhyay S, Schellhorn HE (1994) Induction of Escherichia coli hydroperoxidase I by acetate and other weak acids. J Bacteriol 176(8):2300-2307. https://doi.org/10.1128/jb.176.8.2300-2307.1994

Neidhardt FC, Bloch PL, Smith DF (1974) Culture medium for enterobacteria. J Bacteriol 119(3):736-747. https://doi.org/10.1128/JB.119.3.736-747.1974

Oh HY, Lee JO, Kim OB (2012) Increase of organic solvent tolerance of Escherichia coli by the deletion of two regulator genes, fadR and marR. Appl Microbiol Biotechnol 96(6):1619-1627. https://doi.org/10.1007/ s00253-012-4463-8

Okai Y, Sato EF, Higashi-Okai K, Inoue M (2004) Effect of endocrine disruptor para-nonylphenol on the cell growth and oxygen radical generation in Escherichia coli mutant cells deficient in catalase and superoxide dismutase. Free Radic Biol Med 37(9):1412-1418. https://doi.org/10.1016/j. freeradbiomed.2004.07.001

Ramos JL, Duque E, Gallegos MT, Godoy P, Ramos-Gonzalez MI, Rojas A, Teran W, Segura A (2002) Mechanisms of solvent tolerance in gram-negative bacteria. Annu Rev Microbiol 56:743-768. https://doi.org/10.1146/annur ev.micro.56.012302.161038

Ruiz-Laguna J, Pueyo C (1999) Hydrogen peroxide and coffee induce G:C $\rightarrow T$ : a transversions in the lacl gene of catalase-defective Escherichia coli. Mutagenesis 14:95-102. https://doi.org/10.1093/mutage/14.1.95

Rutherford BJ, Dahl RH, Price RE, Szmidt HL, Benke PI, Mukhopadhyay A, Keasling JD (2010) Functional genomic study of exogenous $n$-butanol stress in Escherichia coli. Appl Environ Microbiol 76(6):1935-1945. https://doi. org/10.1128/AEM.02323-09

Sakamoto H, Touati D (1984) Cloning of the iron superoxide dismutase gene (sodB) in Escherichia coli K-12. J Bacteriol 159(1):418-420. https://doi.org/ 10.1128/JB.159.1.418-420.1984

Semsey S (2014) A mixed incoherent feed-forward loop allows conditional regulation of response dynamics. PLoS ONE 9(3):e91243. https://doi.org/ 10.1371/journal.pone.0091243

Shimizu K, Hayashi S, Kako T, Suzuki M, Tsukagoshi N, Doukyu N, Kobayashi T, Honda H (2005) Discovery of glpC, an organic solvent tolerancerelated gene in Escherichia coli, using gene expression profiles from DNA 
microarrays. Appl Environ Microbiol 71(2):1093-1096. https://doi.org/10 1128/aem.71.2.1093-1096.2005

Smillie DA, Hayward RS, Suzuki T, Fujita N, Ishihama A (1992) Locations of genes encoding alkyl hydroperoxide reductase on the physical map of the Escherichia coli K-12 genome. J Bacteriol 174(11):3826-3827. https:// doi.org/10.1128/jb.174.11.3826-3827.1992

Touati D (1983) Cloning and mapping of the manganese superoxide dismutase gene (sodA) of Escherichia coli K-12. J Bacteriol 155(3):1078-1087

Triggs-Raine BL, Doble BW, Mulvey MR, Sorby PA, Loewen PC (1988) Nucleotide sequence of katG, encoding catalase HPI of Escherichia coli. J Bacteriol 170(9):4415-4419. https://doi.org/10.1128/jb.170.9.4415-4419.1988

Tsukagoshi N, Aono R (2000) Entry into and release of solvents by Escherichia coli in an organic-aqueous two-liquid-phase system and substrate specificity of the AcrAB-TolC solvent-extruding pump. J Bacteriol 182(17):4803-4810. https://doi.org/10.1128/JB.182.17.4803-4810.2000 Watanabe R, Doukyu N (2012) Contributions of mutations in acrR and marR genes to organic solvent tolerance in Escherichia coli. AMB Express 2(1):58. https://doi.org/10.1186/2191-0855-2-58

Watanabe R, Doukyu N (2014) Improvement of organic solvent tolerance by disruption of the lon gene in Escherichia coli. J Biosci Bioeng 118(2):139144. https://doi.org/10.1016/j.jbiosc.2014.01.011

\section{Publisher's Note}

Springer Nature remains neutral with regard to jurisdictional claims in published maps and institutional affiliations.

\section{Submit your manuscript to a SpringerOpen ${ }^{\odot}$ journal and benefit from:}

- Convenient online submission

- Rigorous peer review

- Open access: articles freely available online

- High visibility within the field

- Retaining the copyright to your article

Submit your next manuscript at $\mathbf{s p r i n g e r o p e n . c o m ~}$ 